\title{
From the reign of terror to the reign of peace: The role of state, religions and church in God's mission amidst terror
}

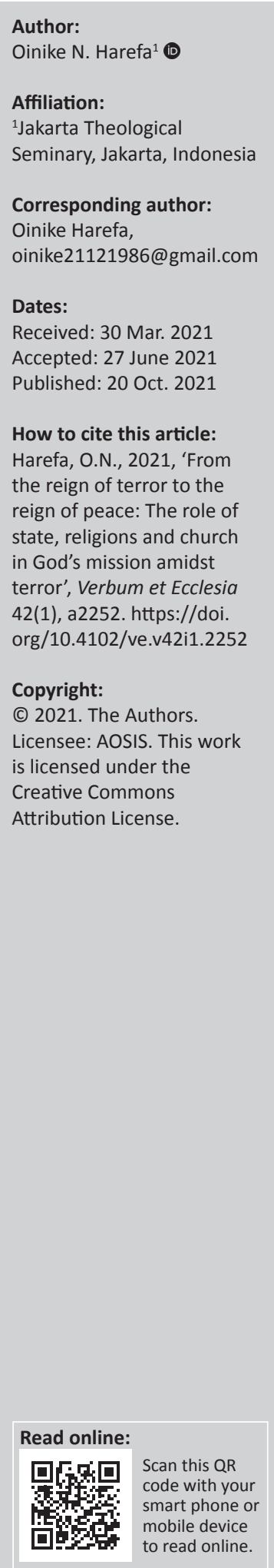

Terrorism in the name of religion continues to occur in various places around the world. Religious motives are often used as the basis for acts of terrorism. This article studies whether the roots of violence in religions tend to encourage terrorism and how religions, especially Christianity, can take part to overcome terrorism. In the first part, it examined the roots of violence, specifically in three world religions: Judaism, Christianity and Islam. The second part discusses the role of the state and religions in combating terrorism. In the third part, this article offers a theology of mission amidst terror and how the church participates in this calling. Religion cannot be used to justify terrorism; therefore, there is a need for theology of mission to give a theological basis towards peace. Religions together with the state take part to combat terrorism. This research is limited to the three religions, namely Judaism, Christianity and Islam. This article utilised literature research. It also specifically included the context of Indonesia.

Intradisciplinary and/or interdisciplinary implications: The article considers political and socio-economic factors besides religious motives that cause terrorism. This article challenges theology of mission amidst the terror and contributes to practical theology such as the role of the state and religions, specifically Christianity on the role of the church towards peace.

Keywords: terror; holy war; religion; state; church; mission; peace.

\section{Introduction}

Terrorism comes from the word terrere (Latin), which means 'to cause tremble' (Jurgensmeyer 2000:5). This term has been well known since the French Revolution around the 18th century. Mark Juergensmeyer defined terrorism sociologically as public acts of demolition that were committed without a clear military objective and that cause an extensive sense of fear. Terrorism is often associated with violence committed by marginalised groups to gain power or influence. Terrorism is also understood from the world view: when the world is apparently peaceful, violent acts emerge as terrorism. If the world is apparently in war, violent acts are possibly considered legitimate.

C.A.J. Coady defined terrorism based on the ethical side. For him, terrorism is the use of violence to attack non-combatants or innocent parties for political purposes (Coady 2004:772-789). He rejected to define terrorism politically as violence by those who are unlawful to use it or as a direct attack on people whom we have no authority to kill. Furthermore, Coady agreed on the principle of discrimination as part of the terror for states in a 'supreme emergency'.

Regarding the use of the principle of discrimination in defining terrorism, Noam Zohar shows concerns that it could permit the unjustifiable killing of non-combatants and guiltless bystanders (Zohar 2004:734). David Rodin, who stands against the traditional use of the principles of discrimination, argues that placing too much power on target results can lead to irresponsible attacks on noncombatants or innocent persons. Terrorism is 'the deliberate, negligent, or reckless use of force against non-combatants' (Rodin 2004:775).

Many countries around the world have experienced being targeted by terrorism. In Asia, Indonesia is one of them. Indonesia is supposed to be the home of several world religions such as Islam, Buddhism, Christianity, Hinduism and Confucianism. It is also a home for streams of beliefs such as Kejawen, Sunda Wiwitan, Parmalim, Marapu and Kaharingan. Indonesia has a motto, Bhinneka Tunggal Ika (Sanskrit), which means unity in diversity. Yet, Indonesia has been targeted by terrorism in the name of religion. There are some reasons for this. Firstly, Indonesia 
has become a fertile field for accusers of Wahhabi who spread their belief that they are the truest believer of Islam. Secondly, the sympathisers of radical Islamic movements in Indonesia are increasing every year which is marked by the success in brainwashing students, civil servants, urban middle class and professionals through recitations and assemblies that spread hatred and intolerance. Thirdly, the existence of religious teachers who support radical understanding and radical movements. They allow for acts of intolerance, acts of violence and or terrorism. In Indonesia, provisions in Law Number 5, year 2018, Chapter I Article 2, terrorism is defined as:

$[A] \mathrm{n}$ act that uses violence or threats of violence that creates an atmosphere of widespread terror or fear that can cause mass victims, and/or cause damage or destruction to strategic vital objects, the environment, public facilities, or international facilities with ideological, political, or security instability. (Widodo 2018)

From the year 2000 up to 2021, there are more than 10 lists of terrorist acts that happened in Indonesia. Parts of the list details bombs that exploded simultaneously at 11 churches on 24 December 2000, killing 19 people and injuring around 100. The Al-Qaida based in Southeast Asia is blamed for these acts. In 2002, the terrorist act killed more than 200 people in Bali. On 05 August 2003, a bomb in front of the J.W. Marriott Hotel in Jakarta killed 12 innocents and wounded 150. On 31 December 2003, a bomb in Aceh killed 10 people. On 10 January 2004, a bomb killed four people in a karaoke café in Palopo, Central Sulawesi. On 09 September 2004, a bomb exploded close to the Australian Embassy in Jakarta and killed three people and wounded 100. On 01 October 2005, there was a suicide bombing in Bali which killed 23 people, including the three bombers. On 31 December 2005, a bomb exploded at a market in Palu, killing seven people. On 07 July 2009, suicide bombers killed more than 50 people in the RitzCarlton and J.W. Marriott hotels in Jakarta. On 14 January 2016, a bomb at a Starbucks café in central Jakarta killed two civilians. On 24 May 2017, a bomb at Kampung Melayu, Jakarta, killed three police officers. On 28 November 2020, there was a terror act in Sigi that killed four people. The last case happened on 28 March 2021, the act of terror happened in Makassar.

This article aims to analyse whether religions justified terrorism. To answer this question, this article is organised into three parts. The first part scrutinises the roots of violence in religion, especially in Judaism, Christianity and Islam. The second part examines the role of the state and religions in combating terrorism. In the last part, this article offers a theology of mission amidst terrorism. My argument is that terrorism in the name of religion cannot be used to justify violence; therefore, it is crucial for every religion to give a theological basis towards peace. Religions together with the state take part in combating terrorism.

\section{The root of violence in religions justifies terrorism? \\ In Judaism}

The nature of violence in the Hebrew Bible is described as earthly realism. It is a sign of evil power. Hans Küng considered Rene Girard, who has elaborated acts of violence in ancient cultures. According to Girard, violence was veiled in silence, polished and overvalued in mythologies (Küng 2005:253). The Bible frequently reversed the subject of violence to the confrontation of the violent nature of human beings. It can be observed from the series of competitions between Cain and Abel, the anti-war preaching of the prophets, a vision of peace amongst nations established by God and non-violence as a proposal for the movement of peace today (Is 2:4, Mi 4:1-3).

There are narrations of wars and violence in the overall context of the Hebrew Bible. In the story of human creation, the purpose is not about who is the first person in the Garden of Eden, but to describe the human conditions. The term adam means the person who is created in God's image. However, humans rebel against God. The series of violence started from the story of Cain who killed his brother Abel. The climax of the story is reached when God allowed the flood to solve the problem of violence. Humans on earth were 'corrupt in God's sight, and the earth was filled with violence' and was therefore doomed to destruction (Gn 6:11-13). The only righteous were Noah and his family. Their descendants were enabling sustainable humankind on the earth. It is a symbol of God's covenant with all humankind and the whole creation.

God protects human life with sanctions against violence, 'for God made human in God's own image' (Gn 6:9). God's covenant is in harmony with a code of ethics based on the principle of respect for life. From this code of ethics, Rabbinic Judaism derived the Laws of Noah which prohibits the murder of humans and cruelty to animals. It also prohibited idolatry, robbery, blasphemy and adultery. This code of ethics included a positive command towards justice (courts established). It also constitutes a universal code of conduct that encompasses all human beings.

\section{In Christianity}

Christianity has a right to be a state religion in the period of the old Roman Empire. The state and church used their powers to protect and sustain each other. There was an intertwined domain of the sacred and the profane. The state became the protector of the church and the church legitimised and inspired the state in many circumstances. On the one hand, an expansion of the state led to the expansion of the church. On the other hand, missionary work by the church led to an expansion of secular domination. State law and church law complemented each other. In this way, the state and Christianity gave mutual support to each other. But the secular acts of violence without doubt cast a shadow 
over Christianity because the church often participated actively in violence.

In the High Middle Ages, there was the term 'holy war'. The Augustinian theory was used to support the Latin Christianity of the west to use force to achieve spiritual purposes. It permitted violence to spread Christianity. However, it was contrary to the older tradition of the early church to convert the sinners, spread the Gospel and battle heresy. The Crusades as a 'holy war' became the absolute reverse of following Christ. This war was initiated by Pope Urban II and Bernard de Clairvaux, Christianity's supreme representatives who paid war to wrest the 'Holy Land' from the Muslims. The series of Crusades was considered as a matter for (western) Christianity as a whole. The Pope legitimated as the spokesman of Christ called people to arms.

Alongside this period, many Christians wondered whether Jesus has commanded the war. On the Sermon on the Mount, Jesus preached about peace, non-violence, love. His word is inspiring Christians to bear their cross. The word of Jesus is not about the Crusade that dressed to legitimise bloody wars against other faiths.

\section{In Islam}

The term 'holy war' does not appear in the Koran. According to Islamic understanding, a war can never be 'holy'. However, there is a term of jihad. It is understood as an authoritative 'struggle' or 'battle' as stated, 'Have faith in God and His apostle and fight for God's cause with your wealth and your persons' (Küng 2005). Islam is militant in nature when the Muslim community is threatened with violence. Jihad in Islam is understood as a willingness to fight to make peace. For example, it is stated in the peace treaty with the Meccan, Christian communities and the remaining Jews. In the time of hunting for slaves, the population against the jihad was directed to adopt Islam. If they surrendered, the people could have the position of 'protected persons', otherwise their conquest led them to slavery.

In modern times, jihad was under pressure from European colonialism. In the twentieth century, the ideologists of radical Islam understood jihad as no longer about the external fight for freedom from colonialism, but also against their own westernised government that allegedly was against the practice of Islam. Furthermore, the term jihad is also used in political notions such as the military term 'campaign' that lead to the meaning of the fight against underdevelopment, tourism, economic reform or the murder of liberal politicians (Küng 2005). Since the 1970s, a radical understanding of jihad has been clear amongst religious extremist groups. Since the bombing on 11 September 2001 in America, the intolerably ambivalent part played by Saudi Arabia, America's greatest partner in the Arab Middle East, has become increasingly clear. It is not only in conditions of oil exports but also terrorism export.
We cannot deny that there are roots of violence in the three religions. We also can find the roots of love and peace. In Judaism, God protected human life with sanctions against acts of violence. There is a code of ethics based on God's covenant to the principle of respect for life. It is a universal code of conduct for all human beings. In the history of Christianity, there was a 'holy war' that was used to force the spreading of Christianity. It was contrary to the old tradition of the early church. However, in Jesus Sermon on the Mount, he taught of non-violence and love. In Islam, there is a word jihad which is understood as a powerful 'struggle' or 'battle' to defend the victims of violence. So, the concept of jihad in Islam is not only a willingness to fight but also the willingness to make peace. From this understanding, the historical violence in the past in each religion cannot be used to justify terrorism today.

Charles Kimball mentioned that there are five warning signs when religion turns evil (Kimball 2002). The first is the absolute truth claims. The second is blind obedience. The third is establishing the 'ideal' time. The fourth is the end that justifies any means. The last is declaring holy war. These five warning signs can be used to scrutinise every religion whether it has these tendencies or not.

On a wider paradigm, terrorism today is not only caused by religious factors but also political, economic and the willingness to dominate others. Sya'afatun Almirzanah argued that terrorism is not only an act based on religious motivation (Almirzanah 2011:24). Kirsten E. Schulze emphasised the similar thought that terrorism is also connected to the academic process, socio-economic, political and territorial complaints (Schulze 2002). For example, the conflict in Aceh, Indonesia was viewed as the conflict between militant Islam and the government. The war was about political autonomy and control over natural gas resources.

\section{The role of states and religions in combating terrorism The role of state}

In history, there are some responses by the state on how to combat terrorism. In the US after the terrorism case on 9/11, President Bush called for a crusade against terror. His statement became a cause for the spread of global conflict in apocalyptic language. This response raised questions about whether the war on terror was the proper ethical response to the attacks on Al Qaeda. John Mueller reported that the US has constantly overstated international terrorist intimidation. He argued that the nation's overreaction to terrorism can create insecurity, fear and hysteria for many people. 'A war on terror' is invented to defend. He added that 'efforts against terrorism should be considered more like a campaign against crime than like a war' (Mueller 2005:208-234).

In Indonesia, the government combats terrorism with coordination within three organisations; they are the national 
intelligence, military intelligence and counter-terrorism unit of the police. There are four steps of the Indonesian government's efforts in dealing with terrorism (Hasanah 2018:881-892). The first is minimising the main causes of terrorism. This soft approach is the de-radicalisation programme. It is a strategy or action that aims to neutralise radical ideas for those involved in terrorists and their sympathisers and community members who have been exposed to radical ideas, through re-education and re-socialisation and instilling multiculturalism. In its implementation, de-radicalisation is divided into two parts, namely the preventive section and the rehabilitation section. The second is the counterattack. This step is to form a military force with the specific aim of preventing acts of terrorism. The third is the revision of Law No. 15 of 2003. The Indonesian government discussed revising several articles in Law. In the revision of the Anti-terrorism Law, the efforts that the government wants to increase are prevention. The last is international cooperation both bilaterally and multilaterally. The importance of establishing cooperation and allies is very vital, considering that terrorism is also a transnational crime.

Lee Griffith gives his warning to the state on combating terrorism. He argues that reaction to terror can be more destructive than terror itself (Griffith 2003:225). The greatest compromise to terrorism is mimesis. The battle against terror can imitate terrorist opponents. Griffith rejects the idea of 'war on terror' because history proved that violent and punitive responses tend not to restrain terror but to damage civil and political rights and create more wounded than the terrorist attacks.

Anthony Burke offers the choice of 'just war' as the response to terrorism. He said that 'the just war' theory about discrimination and proportionality tolerates massive, preventable and unfair fatalities of innocent life, as long as it is unintentional or indirect (Burke 2004:329-353). On the other hand, Duncan Forrester sees the theory of 'just war' as too restraining. For him, Christianity needs an ethical war that is more permissive. He offers Christianity's predisposition against violence and seeks for reconciliation needs to inform 'the just war' theory. There is a need for war ethics to control the use of violence. He believed that 'the just war' theory fails to attend adequate psychological and social roots of violence and alternative for conflict resolution (Forrester 2003:64-67).

According to Hans Küng, terrorism cannot be combated by military retaliation. The suicide bombers are not terrified by any military weapons. He proposed that terrorism must be resolved from its root to create peace. The response of the state to terror or violence must consider whether the use of military force is just or not. The resolution against terrorism by the state should include terrorism prevention from the educational level to the commitment of reconciliation and peace. Glen Stassen explores how a 'just peacemaking' paradigm can be an alternative to preventing terrorism instead of just thinking of war (Stassen 2003:171-194).
In the role of the state against terrorism, Luther's 'Two Kingdoms' theory also can be considered. The primary task of the state is to help human beings in the pursuit of justice. This sense of justice becomes the norm or standard of all legal and political laws of civil government, including the decision of the state in dealing with terrorism. Justice specifically means the protection of the weak, the poor and the innocent from the violence and greed of the powerful. The two-fold political is the duty of the Christians. Firstly, Christians should obey the government because it has the authority instituted by God. Secondly, when the state falls under the power of evil and political rulers become tyrannical, Protestants are to exercise their prophetic witness. When the state decides to use military force or war against terrorism, Christians need to remind the state to not fall into the dangerous counter-terrorism law which can lead to abusive authoritarian power.

\section{The role of religions}

Amidst terror or a situation where terror cannot be forgotten and there is a risk of repeating it, religions need to take their role as the agent of hope. The future of religions lies in their ability to indicate hope for the world. In giving hope to the world, religions need to learn from the failure in some experiences in the past. For instance, the concept of martyrdom in the history of Christianity justified the series of crusades and brought Christianity into the dark ages; also the concept of 'wrong' jihad practised by the fundamentalists and radicals in Islam who spread terror by bombing the innocents. This concept is needed to undergo in our new era, for we are in a world in which thousands of innocents are killed because they are subjected to terrorism or violent attacks. How are we to name these deaths and the shedding of the blood of innocents that take place in our contemporary world?

Felix Wilfred gives some keys to how religions can be the agent of hope for a better future (Wilfred 2000:72). First is the demand for a proper hermeneutic which will project the religious traditions towards the future. Second is the follower of different religious traditions need to be trained in the art of negotiating the boundaries to be able to reach out, join hands and journey towards what is yet to come. The third is the question of the necessary shift from faith to love, the implications of which we can see by rethinking the idea of martyrdom. Fourthly, religions need to reflect and discuss together regarding the praxis of hope for transforming the world.

Hope appears on the horizon of humanity to the extent solidarity is in practice. It is the very crucial role of religions. It implies that the religions contribute to the emergence of the world of equity and inclusion, create a culture of peace and tolerance. It is also the challenge of pluralism and interreligious dialogue to address the issue of justice and peace. 


\section{Theology of mission amidst terror towards the reign of peace}

God's mission amidst terror is understood in how God as Trinity is involved in human history. God the Trinity has the mission to liberate Israel from slavery and is the same God who took on human form in Jesus Christ, and who since then continues to inhabit this world. God's mission is to free the world from violence and lead it to the fullness of life - for people of all religions and it encompasses the whole of creation.

In God the Trinity, Christ participates in divine communion. It has implications for mission as efforts of peace-building. God through Jesus Christ and Holy Spirit establishes the reign of peace and justice. Following the way of Jesus Christ, we participate in the dynamics of God's reign of peace; therefore, the mission can be defined as work to transform conflicts, defend human dignity and the sanctity of life, promote just and sustainable communities and build cultures of peace. Peace, therefore, does not begin with a static concept of God, but rather a dynamic one, that expresses the great movement of love within the divine communion. Amidst terror, God's mission is to bring peace to the world.

God's mission in the time of terror is also related to the term oikos. In the Trinitarian concept of God, creations are separate from each other. They are in a deep relationship with each other. It is God's blessing and the life-giving Spirit that maintain the delicate web of relationships in all of creation, which reveals the reality of God - creating and sustaining, healing and redeeming, bringing to fulfilment and reconciliation in peace. The oikos of the world and the church, the oikoumene of God's design and purpose, therefore, are not arbitrary constructs. The oikos finds its meaning and purpose in the communion of love, justice and peace amongst the three persons of the Trinity. With our efforts of peacebuilding, we participate in this communion. Thus, mission as peace-building is not just about repairing what has been broken, but about expanding and completing relationships that make the oikos a mirror of God.

How Christianity can participate in God's mission towards the reign of peace? The World Council of Churches (WCC) in Just Peace Companion mentions several important points as the theological basis:

That God is triune reveals a commitment to communion, to the fullness (pleroma) of creation, and the difference and diversity of creation. God is at once a God of peace and justice, of mercy and truthfulness, all of which are in a profound embrace (Ps 85:10-14). Peace is an embrace of all creation. Our relations with God, with one another, and with the earth are not based on the pursuit of an interest or arbitrary choice. They are the bonds of love. In Jesus Christ, who is our peace (Eph 2:14), God has entered the world, knows our brokenness, embraces our vulnerability, and is reconciling all things in Jesus (Col 1:19-20). As created in the image of God and thus participating in the divine communion, human beings have the potential to build peace and overcome violence. They are called to act as mediators and 'priests of creation' co-operating with
God in resisting the forces of death and destruction. The International Ecumenical Peace Convocation meets under the theme: 'Glory to God and Peace on earth'. They are held together in cruciform fashion - emblematic of the cross of Christ that stands as a sign of our reconciliation with God (the vertical beam) and with all creation (the horizontal beam). Ascending praise is answered by descending peace. Glory to God (doxa) is manifested in the building (praxis) of peace. (Tveit 2016:1)

\section{Church as the agent of peace-building}

God's mission is God's self-revelation as the Trinity who loves the world, God's participation in and with the world, the being and doings of God, which encompasses both the church and the world. Here, the church is called to participate (Bosch 1991:10). The church is called to be a visible sign and instrument of communion with God (Bevans \& Schroeder 2004:9).

The perspective from the Church is important to deal with how Christianity takes part in overcoming terrorism as a standpoint. The church has a calling to participate in God's mission. Systematic definition of the church is not found in the New Testament but it offers extensive images about the reality of the church on the earth and the spiritual side of the church. Some of the images are the church as the Body of Christ, church as the people of God, the church as the temple of the Holy Spirit and the church as communion (Raiser 2012).

The being of the church is a sign of the reign of God and the doing of the church is becoming the agent of peace and reconciliation. In the celebration of the Eucharist, it is the moment for us to remember and re-present how God creates peace and reconciles. It reminds us of what God has already done for us in Jesus Christ and Holy Spirit. In multi-coloured ways, the liturgy demonstrates how the peace of God is communicated to us. The church has a calling to share the peace of God into the world.

In dealing with the world problem, especially terrorism, the church cannot work alone but must work together with other churches as one body of Christ. This is why divisions within Christianity have been apparent as a community. Churches must continually examine the theology and actions in the light of the gospel. The Gospel leads us to repent and to look for forgiveness. Thus, the ministry of the churches shows the eagerness to embrace vulnerability and to have a commitment to stand with the poor and marginalised.

The church fulfils its purpose when it becomes a sign and instrument of God's mission to the world. The church is called to participate in concrete action of a 'just peace'. 'Just peace' is a way of life. In a world overwhelmed by violence and controlled by various destructive forces, just peace means refining a spiritual posture. Here, spirituality means deepening our state of mind and connecting in spiritual practices with the community which leads to a deeper 
relationship with the mystery of Christ. Jesus' life teaches us about the reign of peace. In the Sermon of the Mount, Jesus said, 'Blessed are the peacemakers, for they will be called children of God' (Mt 5:9, NRSV). In his life, Jesus also shows us the meaning to be the living prophetic Word of God, both in word and in action. Christianity is called to follow Christ's prophetic word and action, to work for transformation towards peace on the earth.

The church is defined by its identity: being and doing. The identity of the church not only proclaims the coming reign of God but also participates in presenting that vision through the church's life and actions. It is essential for the church to assert dignity and human rights, so the church can promote to implement power in non-oppressive ways.

Olav Fykse Tveit, the former general secretary of WCC, understood in combating terrorism, the role of Christianity through the church and the role of other religions cannot be separated (Tveit 2016:1). He quoted David Nabarro who mentioned seven characteristics of religious communities towards peace, they are:

$[P]$ romoting the inclusion of different groups; offering peaceful channels for conflict resolution; upholding the human rights of the most vulnerable; reminding political leaders of their duty to enable all people to realize their rights; helping ensure that investment takes place in communities, with people at the local level making those investments with their own resources; mobilizing people everywhere, especially young people; and sharing expertise on how to deliver services to those who are hardest to reach. (p. 1)

The church has a calling to respect human rights. The essential value that was embraced by the church towards a just peace is shalom, development and hope. WCC sees the urgent need for the church's capacity to face religious violence and terrorism based on extreme radical beliefs that deny the dignity of others. There is also a need for cooperation sharing human development concerns.

Churches and other religious communities are engaged in humanitarian response and development because of the fundamental faith commitments to respect human dignity, serve the community, protect creation and witness to God. Faith is our basic reason to express and bring it into action. Hope is an essential value of faith. From a Christian perspective, the church's role must base on faith which is prophetic, critical, transformable, bringing hope and love.

Theology of mission amidst terror needs to be led by the vision of shalom in the Bible (Is 54:10; 65: 17-25). This involves a call to become and construct communities of shalom. The concept of shalom can help Christianity to connect with other Abrahamic traditions. Other religious traditions also sustain parallel visions. Shalom reminds us of our relationship with the creation as an affirmation of universal character. Therefore, the church can work together to achieve the same vision in partnership with other religions, communities or institutions. It is in line with the mission of God for the vision of peace, love and justice. This mission also helps the church not only to discuss the vision internally but also to move and to take action towards peace by working together with people of other faiths.

\section{Conclusion}

God's mission amidst terror is transforming the reign of terror (fear) to the reign of God which is characterised by peace, love and justice. The historical roots of violence in every religion cannot be used to justify terrorism. In Judaism, there is a concept of God's covenant based on the principle of respect for life. In Christianity, there is Jesus Sermon on the Mount. Jesus preached about peace and non-violence. In Islam, there is the concept of jihad but firstly, it is about a willingness to fight to make peace. In these religions, there are rich narrations of peace that is needed to be spread more rather than narrations of hatred and terror.

On the other hand, terrorism is not only a religious problem but also a political and socio-economic problem. Therefore, combating terrorism is not only the duty of religions but also the task of many parties. The state, religions and other institutions need to work together towards peace.

In Christianity, the church as the body of Christ on the earth has a calling to participate in God's mission to move towards the reign of peace. The situations amidst terror led Christianity to articulate again how to be the agent of peace. The reign of peace calls us the new understanding of being a church amongst people with different faiths and how to work together with them. The reign of peace is where the state, religions and church can work together to deal with terrorism and create peace in the world.

\section{Acknowledgements Competing interests}

The author declares that she has no financial or personal relationships that may have inappropriately influenced her in writing this article.

\section{Author's contributions}

O.N.H. is the sole author of this article.

\section{Ethical considerations}

This article followed all ethical standards for research without direct contact with human or animal subjects.

\section{Funding information}

This research received no specific grant from any funding agency in the public, commercial or not-for-profit sectors.

\section{Data availability}

Data sharing is not applicable to this article as no new data were created or analysed in this study. 


\section{Disclaimer}

The views and opinions expressed in this article are those of the author and do not necessarily reflect the official policy or position of any affiliated agency of the author.

\section{References}

Almirzanah, S., 2011, 'The peace brokers women of Aceh and Ambon', in F. Shirazi (ed.) Muslim women in war and crisis: Representation and reality, pp. 24-36, University of Texas, Austin, TX.

Bevans, S.B. \& Schroeder, R.P., 2004, Constants in context: A theology of mission for today, Orbis Books, Maryknoll, NY.

Bosch, D.J., 1991, Transforming mission: Paradigm shift in theology of mission, Orbis, New York, NY.

Burke, A., 2004, 'Just war or ethical peace? Moral discourses of strategic violence after 9/11', International Affairs 80(2), 329-359. https://doi.org/10.1111/j.14682346.2004.00386x

Coady, C.A.J., 2004, 'Terrorism, morality, and supreme emergency', Ethics 114(4), 772-789. https://doi.org/10.1086/383440

Forrester, D.B., 2003, 'Violence and non-violence in conflict resolution: Some theological reflections', Studies in Christian Ethics 16(2), 64-79. https://doi. org/10.1177/095394680301600205

Griffith, L., 2003, The war on terrorism and the terror of God, Eerdmans, Grand Rapids, MI.

Hasanah, N., 2018, 'Upaya Pemerintah Indonesia Dalam Mengatasi Terorisme Pada Masa Pemerintahan Joko Widodo Tahun 2014-2019', eJournal IImu Hubungan Internasional 6(3), 881-892.

Hefner, R.W. (ed.), 2001, The politics of multiculturalism and citizenship in Malaysia, Singapore, and Indonesia, University of Hawai'i Press, Honolulu.
Jurgensmeyer, M., 2000, Terror in the mind of God: The global rise of religious violence, University of California Press, Berkeley, CA.

Kimball, C., 2002, When religion becomes evil: Five warning signs, Harper San Fransisco, New York, NY.

Küng, H., 2005, 'Religion, violence and Holy Wars', International Review of the Red Cross 87(858), 253-268. https://doi.org/10.1017/S1816383100181329

Mueller, J., 2005, 'Simplicity and spook: Terrorism and the dynamics of threat exaggeration', International Studies Perspectives 6(2), 208-234. https://doi. org/10.1111/j.1528-3577.2005.00203.x

Raiser, K., (ed.), 2012, Just peace companion, WCC Publications, Geneva.

Rodin, D., 2004, 'Terrorism without intention', Ethics 114(4), 752-771. https://doi. org/10.1086/383442.

Schulze, K.E., 2002, 'Laskar Jihad and conflict in Ambon', Brown Journal of World Affairs 1 (Spring), 57-70.

Stassen, G.H., 2003, 'The unity, realism, and obligatoriness of just peacemaking theory', Journal of the Society of Christian Ethics 23(1), 171-194. https://doi. org $/ 10.5840 /$ jsce 200323126

Tveit, O.F., 2016, 'The role of religion in sustainable development and peace', in Partners for change: Religions and the 2030 agenda for sustainable development p. 1, WCC Publications, Berlin.

Widodo, J., 2018, Undang-Undang Republik Indonesia Nomor 5 Tahun Tentang Perubahan Atas Undang-Undang Nomor 15 Tahun 2003 Tentang Penetapan Peraturan Pemerintah Pengganti Undang-Undang Nomor 1 Tahun 2002 Tentang Pemberantasan Tindak Pidana Terorisme Menjadi Undang-Undang, viewed n.d., from https://www. kemhan.go.id/itjen/wp-content/uploads/2018/10/uu5-2018bt.pdf.

Wilfred, F., 2000, 'Religions as the agent of hope: Challenges for the new millennium', in P.L. Wickeri, J.K. Wickeri \& D.M.A. Niles (eds.), Plurality, power and mission: Intercontextual theological exploration on the role of religion in the new millennium, p. 72, The Council of World Mission, Hong Kong.

Zohar, N.J., 2004, 'Innocence and complex threats: Upholding the war ethic and the condemnation of terrorism', Ethics 114(4), 734. https://doi.org/10.1086/383444 